\title{
Lithological and geochemical dispersal in till: McAdam area, New Brunswick
}

\author{
Andrew J. Stumpf1, Bruce E. Broster', and Allen A. Seaman² \\ ${ }^{1}$ Quaternary and Environmental Studies Group, Department of Geology, University of New Brunswick, \\ Fredericton, New Brunswick E3B 5A3, Canada \\ 2 New Brunswick Department of Natural Resources and Energy, Minerals and Energy Division, \\ P.O. Box 6000, Fredericton, New Brunswick E3B 5H1, Canada
}

Date Received July 2, 1996

Date Accepted November 1, 1996

\begin{abstract}
Analyses of dispersal patterns for till clasts and matrix geochemistry in the McAdam area, southwestern New Brunswick, are used to define the dominant glacial transport direction in an area of ice-flow complexity, as indicated by multiple and differing striae directions. Dispersal and erosional data indicate that the main (regional) southeastward flow direction was preceded and followed by secondary deviations, due to local influences of topography and substrate and possibly also from changes within the ice mass or surrounding glaciers. Clast trains are traceable from known outcrops, southward over distances greater than $16 \mathrm{~km}$, whereas distinctive geochemical trains are lost within $10 \mathrm{~km}$ of transport, due to homogenization of the till matrix. These results demonstrate that for drift prospecting, transport path and source unit are more clearly delineated by shape and size of till clasts and matrix dispersal patterns, than by analysis of directional indicators caused by glacial erosion.
\end{abstract}

On a recours à des analyses des modes de dispersion des clastes du till et de la géochimie de la matrice dans le secteur de McAdam, dans le sud-est du Nouveau-Brunswick, pour définir la direction du transport glaciaire dominant à l'intérieur d'un secteur caractérisé par la complexité de l'écoulement glaciaire, comme en témoignent les directions multiples et différentes des rayures. Les données relatives à la dispersion et à l'érosion révèlent que la principale direction (régionale) de l'écoulement, l'écoulement vers le sud-est, a été précédée et suivie de déviations secondaires en raison des influences locales de la topographie et du substrat, ainsi que possiblement de changements survenus à l'intérieur de l'amas de glaces ou des glaciers environnants. On peut retracer les parcours des clastes à partir d'affleurements connus sur des distances de plus de $16 \mathrm{~km}$ vers le sud, alors qu'on perd des tracés géochimiques distinctifs à moins de $10 \mathrm{~km}$ de transport à cause de l'homogénéisation de la matrice du till. Ces résultats démontrent qu'en matière de prospection glacio-sédimentaire, on délimite plus nettement le trajet du transport et l'unité d'origine par la forme et la dimension des clastes du till et par les modes de dispersion de la matrice que par l'analyse des indicateurs de direction laissés par l'érosion glaciaire.

[Traduit par la rédaction]

\section{INTRODUCTION}

Dispersal analyses of till lithology and geochemistry have long been used in Canada for drift exploration studies (e.g., Dreimanis, 1958; Shilts, 1976, 1984; Hicock, 1986; DiLabio, 1990). In New Brunswick, several recent studies, including Hornibrook et al. (1991, 1993), Balzer and Broster (1994), Munn et al. (1996), Stumpf (1995), and Broster et al. (in press), examined how changes in glacial dynamics influenced till dispersal patterns.

A dispersal pattern or "train" is composed of anomalous concentrations of debris which demonstrate a distinctive areal pattern, commonly fan or ribbon-shaped. For example, mineral and geochemical concentrations in till often decrease exponentially to background levels down-ice from anomalous sites. Local factors such as topography, outcrop size, competence of bedrock lithology, change in ice-flow direction or velocity, or multiple ice-flow events, will alter the shape and extent of a dispersal train.

In the McAdam area, multiple ice-flow directions have been recorded from several striated bedrock sites (Seaman, 1989, 1991; Stumpf, 1995), implying that the area experi- enced a complex glacial history during the Late Wisconsinan. In this paper we examine contrasts in the dispersal of the geochemical matrix and clast lithologies relevant to the complexity of glacial flow directions in the study area.

\section{LOCATION AND PHYSIOGRAPHY}

The study area is located southwest of Fredericton, New Brunswick and bounded by the International Border (CanadaU.S.A.) to the southwest (Fig. 1). This area comprises the New Brunswick part of the McAdam topographic map sheet (NTS $21 \mathrm{G} / 11$, scale 1:50 000). The area lies within the St. Croix Highlands and the New Brunswick Lowlands Physiographic Divisions (Rampton et al., 1984), subdivisions of Bostock's (1970) Appalachian Region of eastern Canada (Fig. 1). The most striking feature of the local topography is the occurrence of three discontinuous, northeast-southwest trending bedrock escarpments that rise between 70 and $130 \mathrm{~m}$ above local relief. These escarpments occur along bedrock contacts separating lithologies with varying susceptibilities to erosion. 


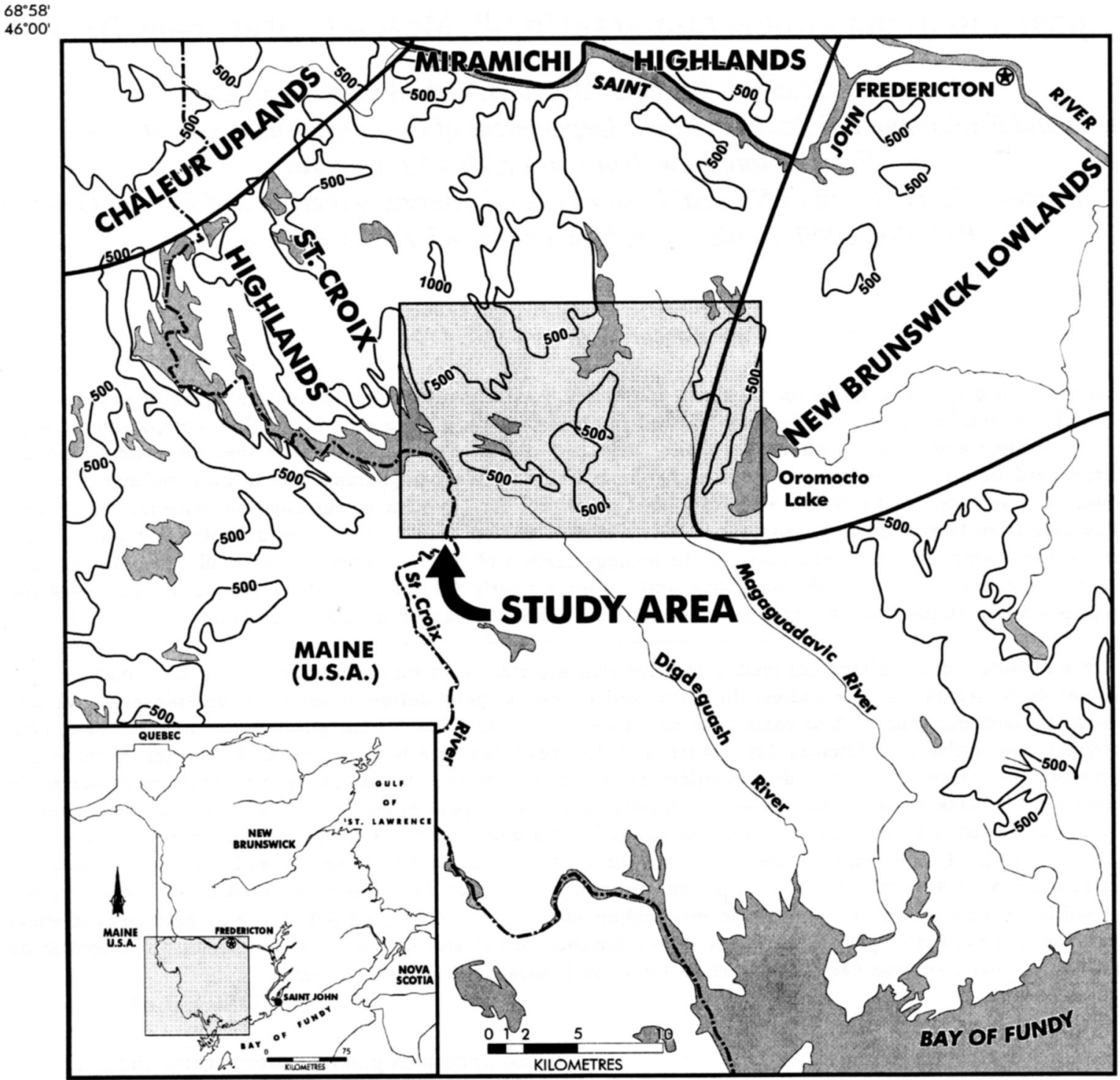

Fig. 1. Location and physiography of southwestern New Brunswick. Contour interval is $500 \mathrm{~m}$. The shaded box outlines the study area.

Major drainage systems in the area, such as the Magaguadavic and St. Croix rivers (Fig. 1), drain toward the southeast. Oromocto Lake and several small rivers along the northern boundary of the study area drain toward the north and east into the Saint John River. Numerous ice-scoured and drift-dammed basins are occupied by lakes and bogs. Streamlined hills, elongated in a northwest-southeast direction, with elevations up to $280 \mathrm{~m}$, are common in the granitic terrain of the northwestern part of the area.

\section{BEDROCK GEOLOGY}

Where exposed, bedrock is commonly weathered to a depth of less than $2 \mathrm{~m}$. Most of the central part of the study area is underlain by sedimentary rocks (some metamorphosed) of the Fredericton Cover Sequence (Fyffe and Fricker, 1987 - Zone 4a; Ruitenberg et al., 1977) including: turbidites of Silurian age, and calcareous and/or micaceous, feldsphathic sandstone and slate of the Flume Ridge and undivided Kingsclear groups (McLeod et al., 1994; Caron, 1996). To the extreme southwest, part of the area is underlain by a fault-bounded unit of unnamed Ordovician pelites and psammites in contact with the Flume Ridge and undivided Kingsclear group rocks (McLeod et al., 1994; Fig. 2).

Silurian granitic rocks of the Pokiok Batholith underlie the northwest quarter of the study area (Fig. 2). The composition of the earliest phase, the Hawkshaw intrusive rocks, ranges from a medium to coarse grained biotite granite to a muscovite-biotite granite or granodiorite (Lutes, 1987). These intrusive rocks are grey to pink, texturally phaneritic to porphyritic and contain xenoliths of metasedimentary and mafic rocks (Lutes, 1987). Younger quartz veins and aplite dykes intrude the Hawkshaw Granite. The Skiff Lake phase intrusive rocks (Fig. 2) underlie the extreme western part of the area and are similar in appearance to the Hawkshaw Granite. 


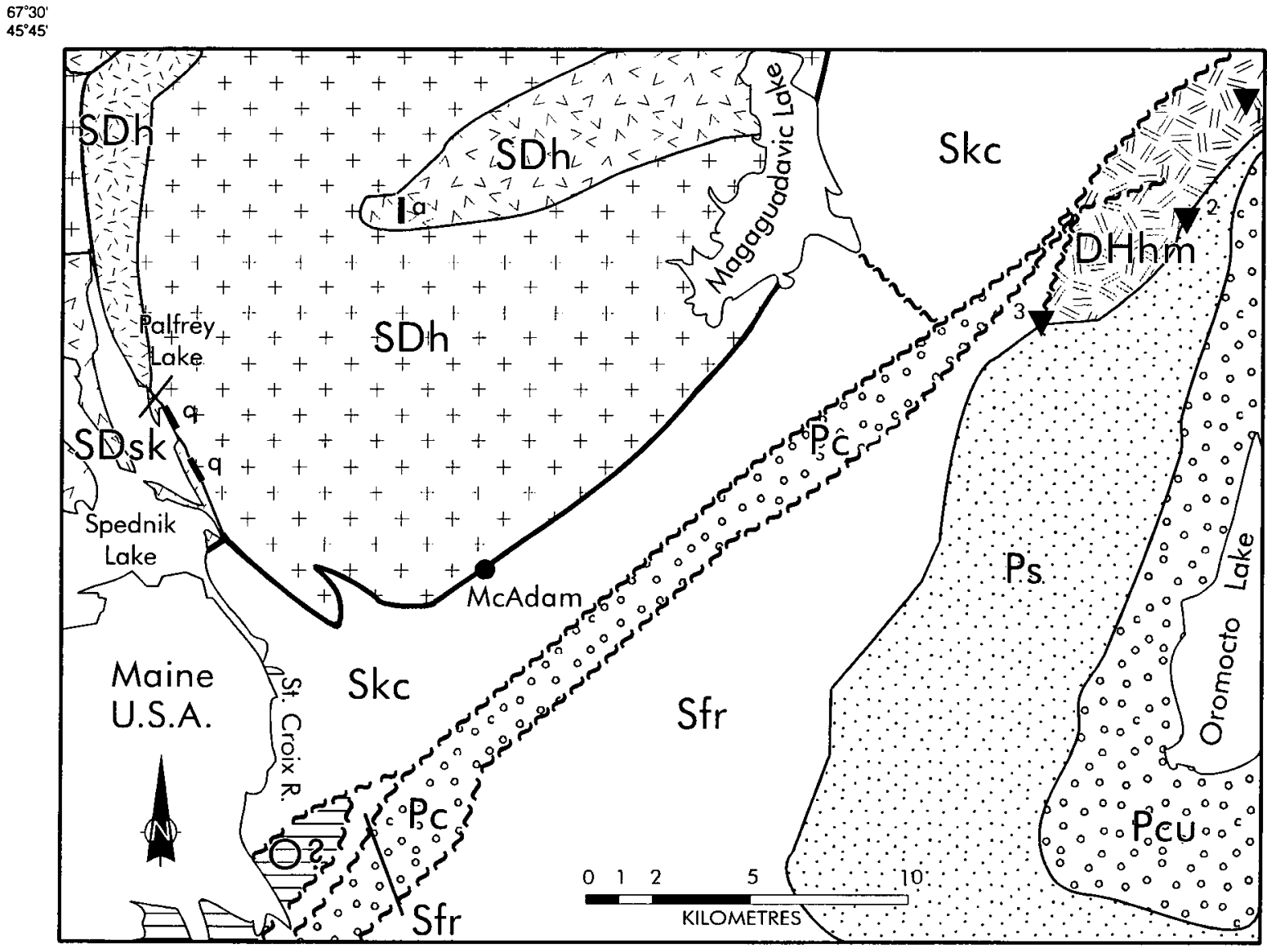

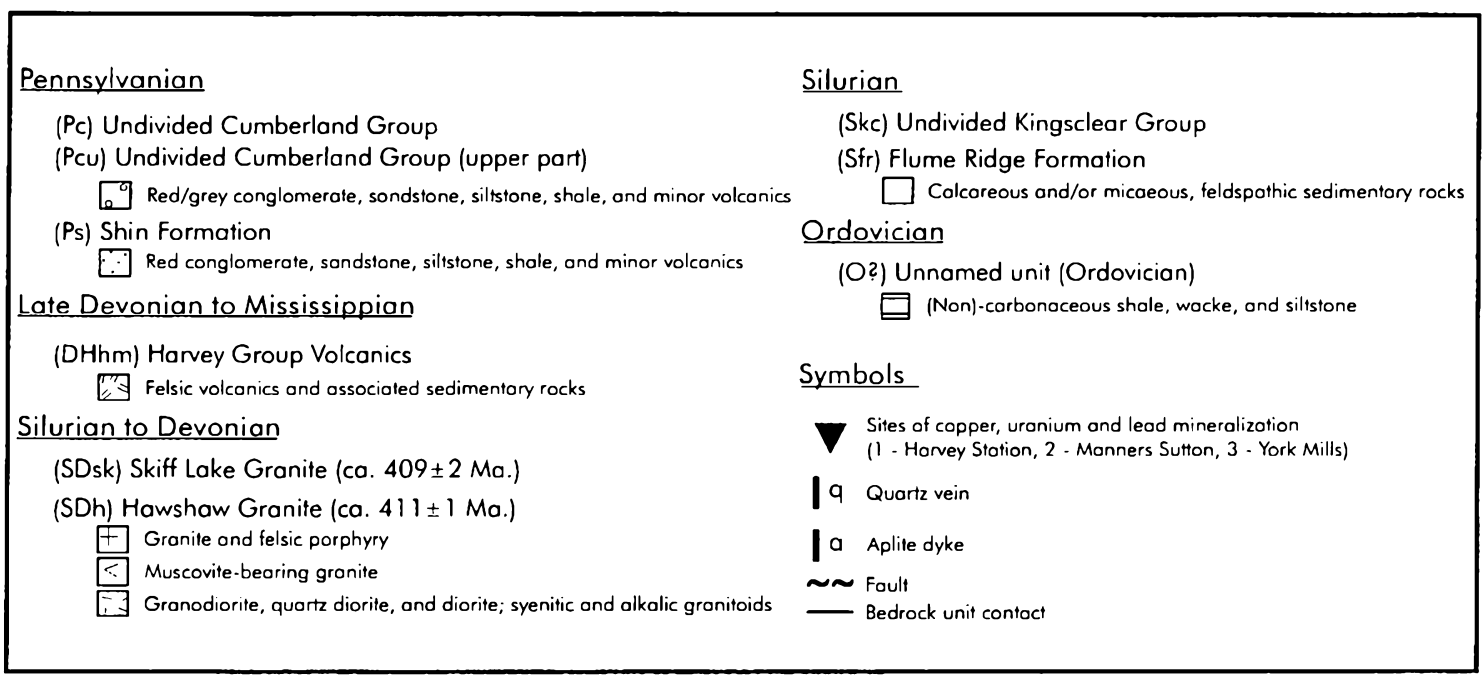

Fig. 2. Bedrock geology of the McAdam area (after McLeod et al., 1994). Note: the Hawkshaw and Skiff Lake granites are phases of the Pokiok Batholith.

In the northeast part of the area, the Carboniferous Cover Sequence, Devonian to Mississippian-Harvey Group felsic volcanic rocks and associated sedimentary rocks, are overlain by redbed sediments of the Pennsylvanian Shin Formation (Clark, 1961a ,1961b; McLeod et al., 1994; Caron, 1996; Fig. 2). Rocks of the Shin Formation are overlain to the east by undivided Cumberland Group Pennsylvanian red/ grey conglomerates, sandstone, siltstone and shale (McLeod et al., 1994; Fig. 2). Fault-bounded, undivided Cumberland Group sediments occur within the Silurian turbidite sequence, forming a thin (1 km wide), northeast-southwest band diagonally crossing the area (Fyffe, 1989; Fig. 2). 


\section{Mineralization}

Known mineral occurrences in the study area occur within the Devonian to Mississippian felsic volcanic rocks. Copper, uranium and lead mineralization occur at Harvey Station, Manners Sutton and York Mills (locations 1, 2 and 3, Fig. 2). Fluorine mineralization is also present in the volcanic rocks at York Mills (location 3, Fig 2; Newell and Bruce, 1956). Mineralization, including scheelite, molybdenite, stibnite and uraninite (Balzer, 1992; Caron, 1996), occurs in the Lake George Mine area, about $15 \mathrm{~km}$ north of the northeastern corner of the study area.

\section{Glacial geOlogy}

The McAdam area is blanketed by an extensive till cover, sporadically overlain by Late Wisconsinan ice-contact and glaciofluvial sediments of variable thickness. Glaciofluvial deposits are particularly widespread around Magaguadavic Lake and Magaguadavic River (Fig. 1), locally reaching several metres in thickness along deglacial meltwater channels (Seaman, 1982). Several eskers trend in a southward to eastward direction across the study area, parallel to the last dominant, regional ice-flow direction (Stumpf, 1995). These eskers comprise part of a dendritic, subglacial drainage system that terminated at glaciomarine deltas along the Bay of Fundy coast (Seaman et al., 1993).

Till cover is composed of a lower, dense lodgement till (occasionally deformation till), commonly grading upwards into a veneer of loose sandy supraglacial or ablation till. The lodgement till is similar in composition and texture to the underlying bedrock, likely due to the incorporation of highly weathered bedrock during glaciation (Broster and Seaman, 1991; Balzer and Broster, 1994; Stumpf, 1995). Locally, areas of ablation till $>2 \mathrm{~m}$ thick, are indicative of zones of ice stagnation (Seaman, 1993). Surface boulder lags are common on till overlying the Pokiok Batholith and the Pennsylvanian sandstones and conglomerates south of Oromocto Lake (Fig. 2).

Large glacial erosional features (drumlins, roches moutonnées) found in the area, indicate a dominant, regional southeastward ice-flow (Gadd, 1973; Rampton et al., 1984). Small-scale features (striae, rat-tails) at several sites, however, imply multiple ice-flow directions (Fig. 3). For example, Seaman (1991) has measured up to ten different striae directions on a single outcrop. Nonetheless, cross-cutting relationships on outcrops in the eastern part of the study area indicate that the last ice-flow in that area was eastnortheastward (Fig. 3).

\section{SAMPle ANAlYSES AND STATISTICS}

Till sampling in the study area was undertaken as part of a surficial mapping project for the New Brunswick Department of Natural Resources and Energy (NBDNRE), Fredericton. Sample collection was carried out by A.A. Seaman in the summer of 1991, A.A. Seaman and T.D. Wood in the summer of 1992, and by A.J. Stumpf and A.A Seaman in the summers of 1993 and 1994. Access to the area was obtained via an extensive network of local and private logging roads, and by canoe. Till samples were collected on a $2-\mathrm{km}$ grid system. The till commonly displayed a 0.5 to 1.0 $\mathrm{m}$ dense lower zone, interpreted to represent basal or englacial till, that graded upward into a loose diamicton interpreted as englacial or ablation till (see Broster et al., in press). Samples were collected only from the dense basal till, at natural exposures and in sample pits excavated to a depth of at least $0.5 \mathrm{~m}$, using stainless steel implements.

A total of 331 samples were collected for grain size and geochemical analyses. The lithologies of 50 to 100 pebbles $(>2.5 \mathrm{~cm}$ in diameter) were determined for 329 samples. Data from an additional 19 sample sites (from Balzer's 1992 study), were included in this study to better define lithological and geochemical dispersal patterns along the northern boundary of the map area.

Granulometric analyses were conducted according to Bouyoucos's (1962) procedure. Geochemical analyses on the silt plus clay size fraction $(<0.063 \mathrm{~mm})$ were performed by Activation Labs Limited (ACTLABS) for 35 elements (Stumpf, 1995). Base metal concentrations were determined by Inductively Coupled Plasma Emission Spectrometry (ICP). Trace and rare earth elements concentrations were obtained using Instrumental Neutron Activation Analysis (INAA). However, the results for only a few of these elements will be discussed here. Anomalous values for elemental concentrations are equivalent to the upper $2.5 \%$ of the data range (after Hawkes and Webb, 1962). Spatial distributions of component abundances were plotted using Surfer for Windows $®$, Version 5.03. Contouring maintained actual values within the control sample grid. Non-parametric, multivariate statistical analyses were performed by the Statistical Package for Social Sciences ${ }^{\circledR}$.

\section{RESULTS AND INTERPRETATION}

\section{Ice-flow history}

Complex ice-flow patterns in New Brunswick have been previously attributed to: (a) the interaction of ice masses from different lobes, (b) different ice caps, (c) proximity to ice divides, or (d) step-wise migration of a single ice lobe (Chalmers, 1902; Gadd, 1973; Rampton et al., 1984; Pronk et al., 1989; Seaman et al., 1993). Detailed surficial geology mapping in the study area (Stumpf et al., 1996) suggests multiple striae directions were produced, as early southeast trending ice was later diverted east-northeastward into the Saint John River valley. Ice-streaming inland, along valleys, may have occurred at the onset of deglaciation. The orientation of 50 prolate clasts at 17 sites indicated two main fabric trends; a northwest-southeast trend, parallel to the main ice-flow direction across the map area, and a northeast-southwest trend. Similar striae orientations indicate that the till fabric data likely represent an earlier ice-flow direction, in part re-oriented by a later change in flow direction (cf. Broster and Dreimanis, 1981), rather than a bimodal (parallel and transverse) fabric. 


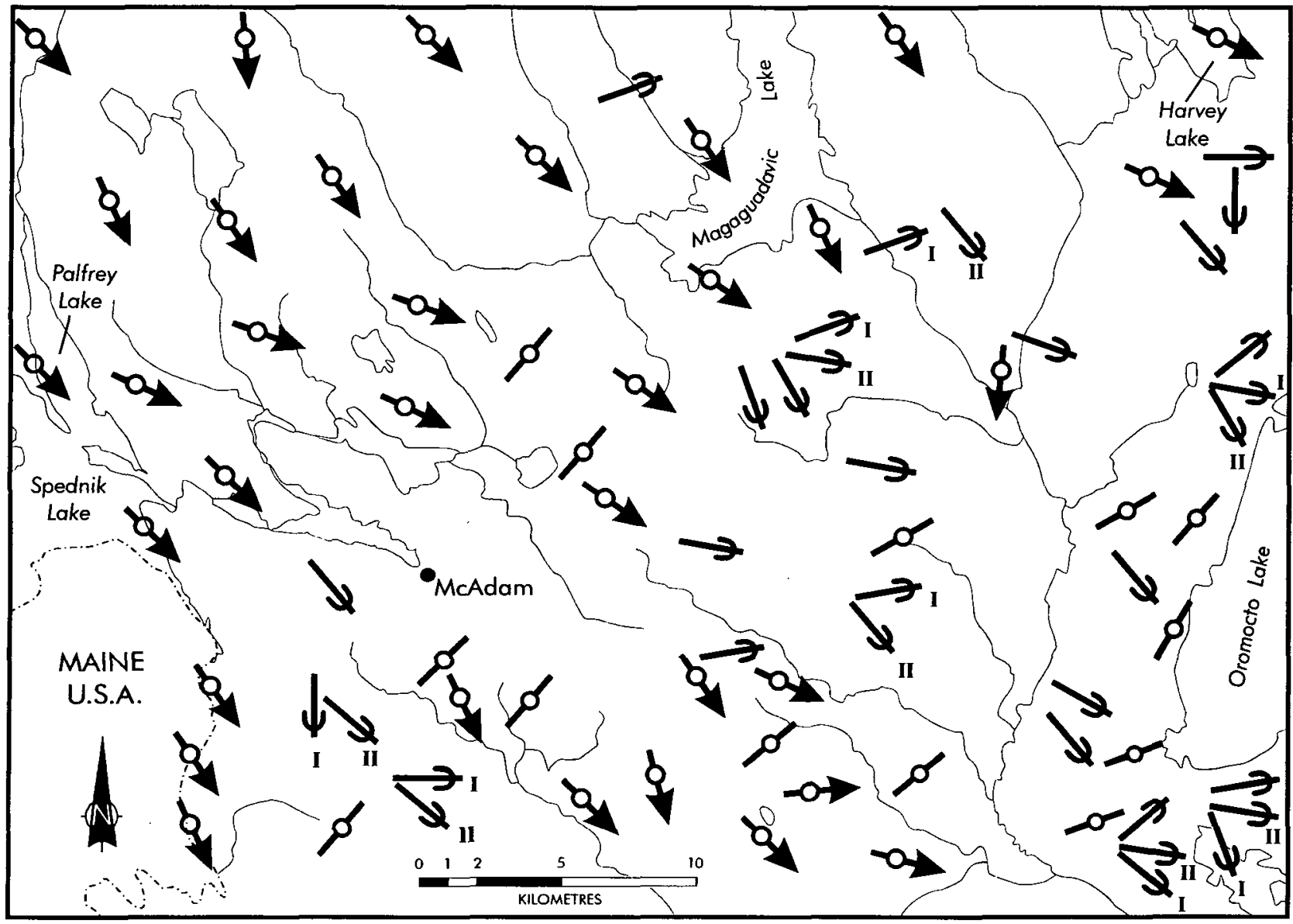

Drumlins
$>$ Glacial flutes
$\begin{aligned} & \text { Striae, glacial grooves (I, II indicate cross- } \\ & \text { cutting relationships) }\end{aligned}$

Fig. 3. Glacial ice-flow patterns from the McAdam area, as indicated by glacial erosional features and striae (I: oldest, II: youngest).

\section{Pebble lithologies}

Local bedrock can be divided into four main lithologic types: granitic (igneous and metamorphic), felsic volcanic, mafic volcanic, and sedimentary (some metamorphosed) rocks (Fig. 2). To facilitate discussion of clast dispersal the study area can be grouped into two main lithologies: (a) the granitic rocks of units comprising the Pokiok Batholith in the northwest third of the area, and (b) sedimentary rocks comprising most of the remaining area. The boundary between rocks of the Pokiok Batholith and rocks of the undivided Kingsclear Group is discussed informally here, as the "granitesedimentary" lithologic contact (Fig. 2).

Granite clast concentrations are highest $(>80 \%)$ in till overlying the Pokiok Batholith, and decrease over a distance of $16 \mathrm{~km}$ southeastward of the granite-sedimentary contact (Fig. 4). In comparison, sedimentary clast abundances are low $(<10 \%)$ in till overlying the Pokiok Batholith (Fig.
5), but are elevated to greater than $60 \%$ in till deposited southward of the granite-sedimentary contact. Sedimentary rocks outcrop about $10 \mathrm{~km}$ north of the eastern part of study area (Balzer and Broster, 1994; Seaman, 1995), likely accounting for a few sedimentary clasts in till overlying the Pokiok Batholith.

At several sites in the southern part of the area, mafic and felsic volcanic clasts have been found which are similar to Silurian-Devonian lithologies outcropping further south. The same lithologies, however, occur as clasts in Carboniferous conglomerate units lying to the north of the study area. This conglomerate unit has been eroded by southward-flowing ice (cf. Broster et al., in press).

\section{Matrix components}

In the McAdam area, the texture and composition of the till changes with variation in the underlying bedrock. 


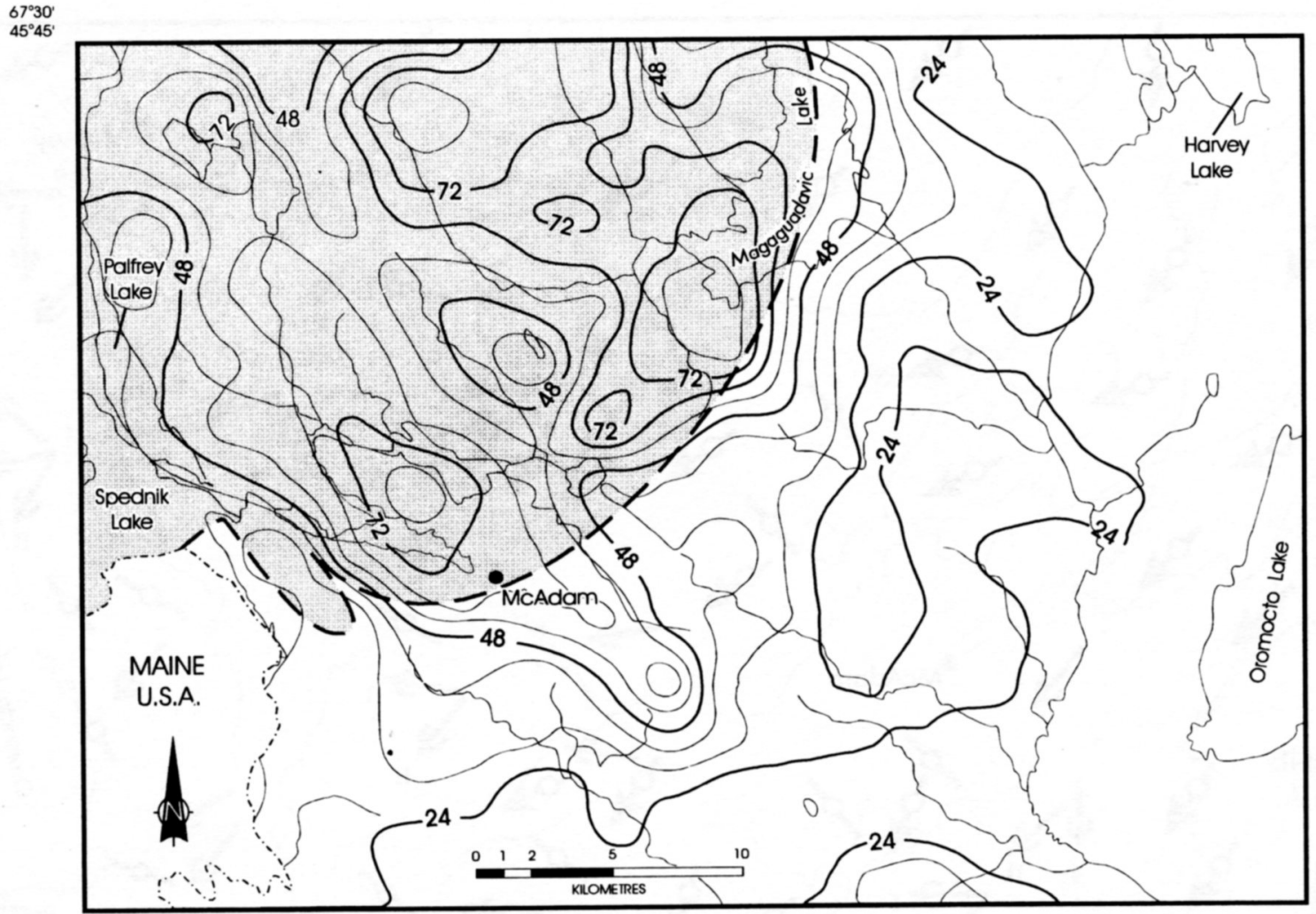

Fig. 4. Percent granite till clasts. The shaded area denotes units of granitic lithologies forming the Pokiok Batholith.

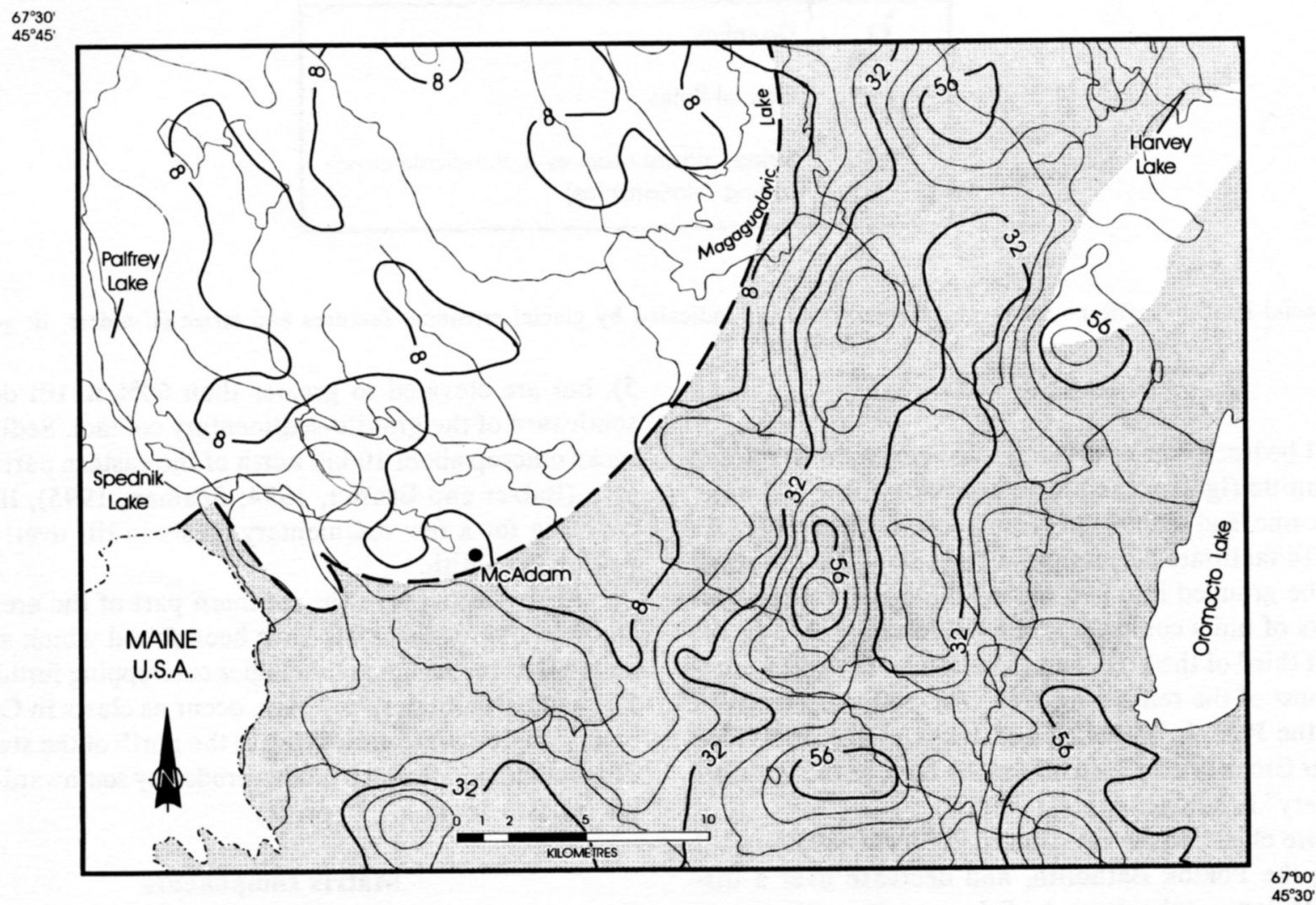

Fig. 5. Percent sedimentary rock clasts till. The shaded area denotes Silurian to Pennsylvanian sedimentary bedrock in the McAdam area. 
For example, till with high sand content (up to 95\%) typically overlies granitic rocks of the Pokiok Batholith. Southeast of the batholith, sand concentration is lower (as low as $25 \%$ ) in till overlying sedimentary rocks of the Fredericton Cover Sequence.

Geochemical abundance, dispersal and covariance were examined for 32 elements in the till matrix. Spearman correlations demonstrated several statistically significant relationships (Table 1). Three groups are clearly identified: (1) significant $\mathrm{Co}$ and $\mathrm{Cr}$ covariance with $\mathrm{Fe}$, and to a lesser extent $\mathrm{Cu}$ with $\mathrm{Co}$ and $\mathrm{Ni}, \mathrm{Mn}$ and $\mathrm{Pb}$ with $\mathrm{Cu}$; (2) a strong correlation between $\mathrm{Th}$ and $\mathrm{U}$; and (3) covariance of rare earth elements (strongest with Sm).

For many elements, concentrations rarely exceed background limits (e.g., Au, Co, Fe, Mo, Ni, Sn; see Stumpf, 1995). No obvious $\mathrm{Pb}, \mathrm{U}$ or $\mathrm{F}$ geochemical anomalies were found in till proximal to known mineral occurrences (Fig. 2), which may be due to the blanketing effect of a thick till cover. Antimony occurs at concentrations of less than 3.0 ppm, and no indication is evident of the antimony-rich bedrock located approximately $12 \mathrm{~km}$ north of the northeast corner of the map area, at the Lake George Mine. However, other chalcophile elements (As, $\mathrm{Hg}$ ) occur in large concentrations ( $>200$ ppm for As, Fig. 6), albeit in small $(<6 \mathrm{~km})$ dispersal trains (see Stumpf, 1995). Where anomalous concentrations exist they form spatial patterns that are circular, "bulls-eye", or southeastward-trending elliptical shapes.

Fourteen lithophile elements $\mathrm{Ba}, \mathrm{Br}, \mathrm{Ca}, \mathrm{Cr}, \mathrm{Cs}, \mathrm{Hf}$, $\mathrm{Mn}, \mathrm{Na}, \mathrm{Rb}, \mathrm{Sc}, \mathrm{Ta}, \mathrm{Th}, \mathrm{U}, \mathrm{W}$ ) were examined (see Stumpf, 1995). The most significant correlation is between Th and $\mathrm{U}(+.97$, Table 1$)$, likely due to their mutual occurrence in anomalous concentrations (e.g., Th, Fig. 7) along the boundary of the Skiff Lake Granite (Fig. 2). Thorium (Fig. 7) concentrations also display a $12 \mathrm{~km}$ dispersal train that is probably due to elevated Th content along a linear bedrock zone subparallel to ice-flow direction, rather than to dispersal from an isolated point-source. Chromium (Fig. 8) and $\mathrm{Rb}$ (not shown), demonstrate elongated patterns, rarely exceeding $10 \mathrm{~km}$ in length, except where longer trains (up to $20 \mathrm{~km}$ ) appear to be linking multiple sources. Chromium (Fig. 8) and $\mathrm{Rb}$ concentration patterns further suggest a possible eastward dispersal in the area north of Oromocto Lake, possibly indicating a late-glacial eastward ice-flow in that area.

Strong positive covariance exists among the rare earth elements (Ce, Eu, La, Lu, Nd, Sm, Tb, Yb), with the strongest relationships between $\mathrm{La}, \mathrm{Nd}$ and $\mathrm{Sm}(\mathrm{r}=.91)$ and $\mathrm{Yb}$ with $\mathrm{Lu}$ and $\mathrm{Sm}(\mathrm{r}=.90$; Table 1$)$. The other rare earth elements, $\mathrm{Ce}, \mathrm{Eu}$, and $\mathrm{Tb}$, also have high correlations with $\mathrm{Sm}$. Most of the rare earth element anomalies are associated with the granite/sedimentary rock contact. For example, the highest $\mathrm{Sm}$ concentrations occur at three different sites along the contact (Figs. 2, 9). The longest Sm dispersal train extends southeastward for approximately $12 \mathrm{~km}$ from the granite-sedimentary rock contact at the south end of Magaguadavic Lake (Fig. 9). Positive correlation between the rare earth elements and Th are likely related to their mutual association with the Pokiok Batholith.

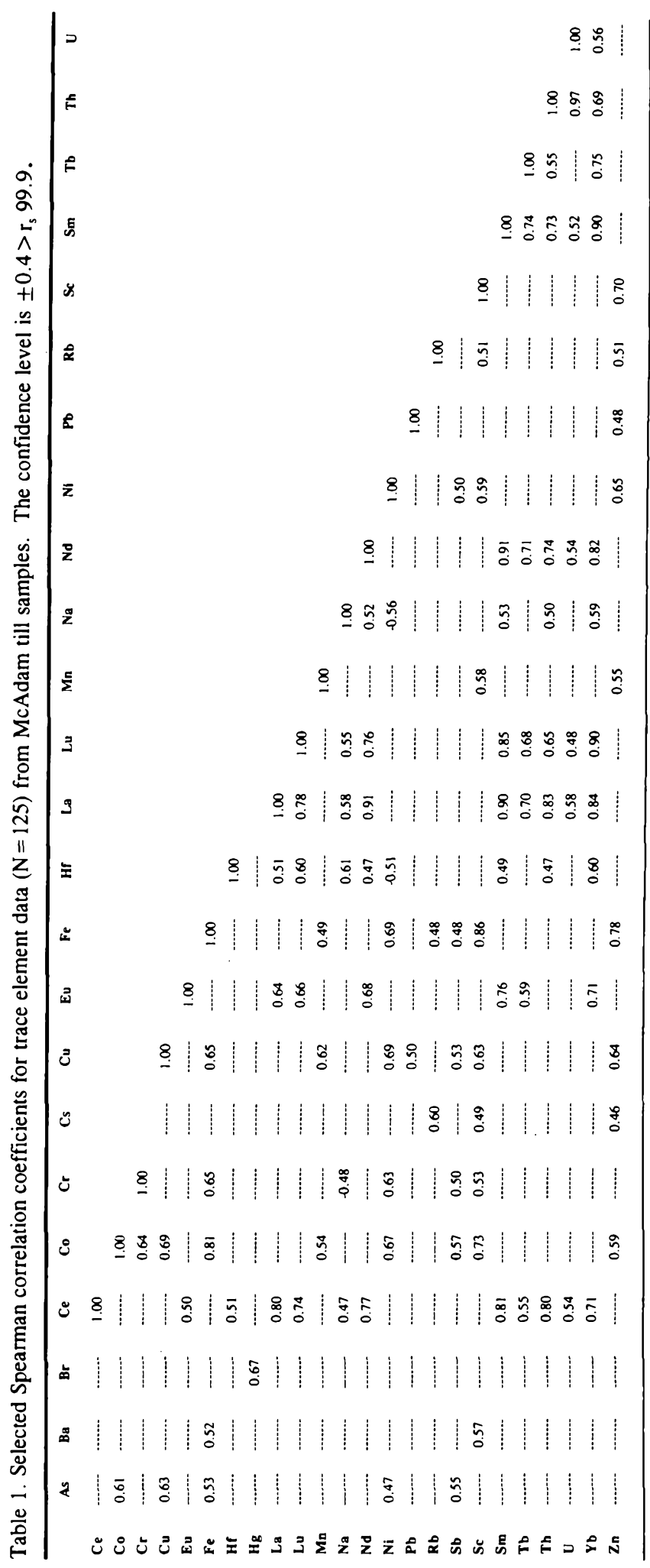

\section{Discussion and conclusions}

With increasing transport distance, grain-size of the glacial load is reduced to the minimum size or "terminal grade" of the constituent minerals (Dreimanis and Vagners, 1971a, 1971b) and locally entrained lithologies are mixed with material in transit (Broster, 1986). In this way even basal tills are 


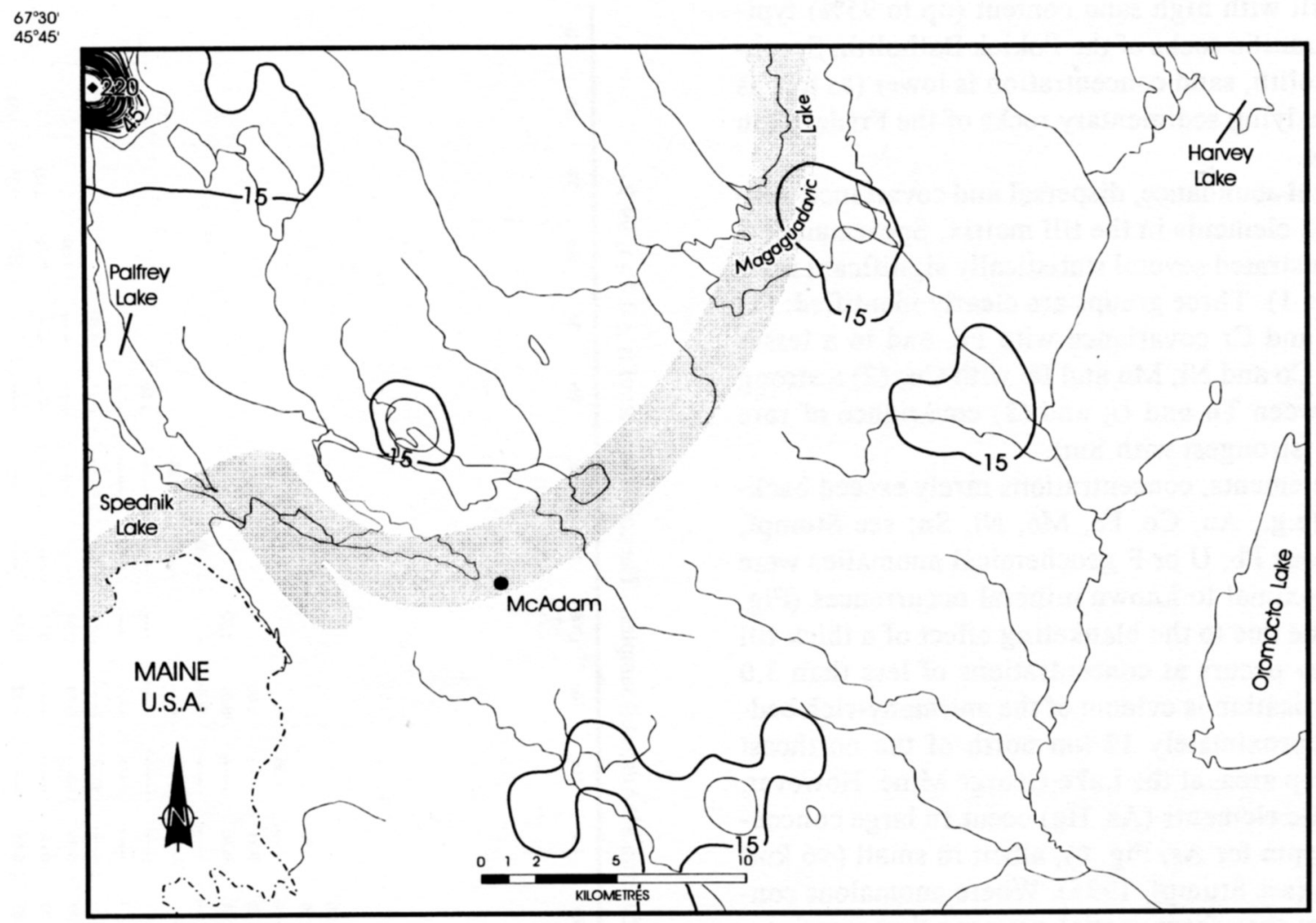

Fig. 6. As concentration in till (contour interval $15 \mathrm{ppm}$ ). The shaded line denotes the approximate granite - sedimentary boundary between units of the Pokiok Batholith to the north and units of Silurian to Pennsylvanian age, containing sedimentary rocks to the south.

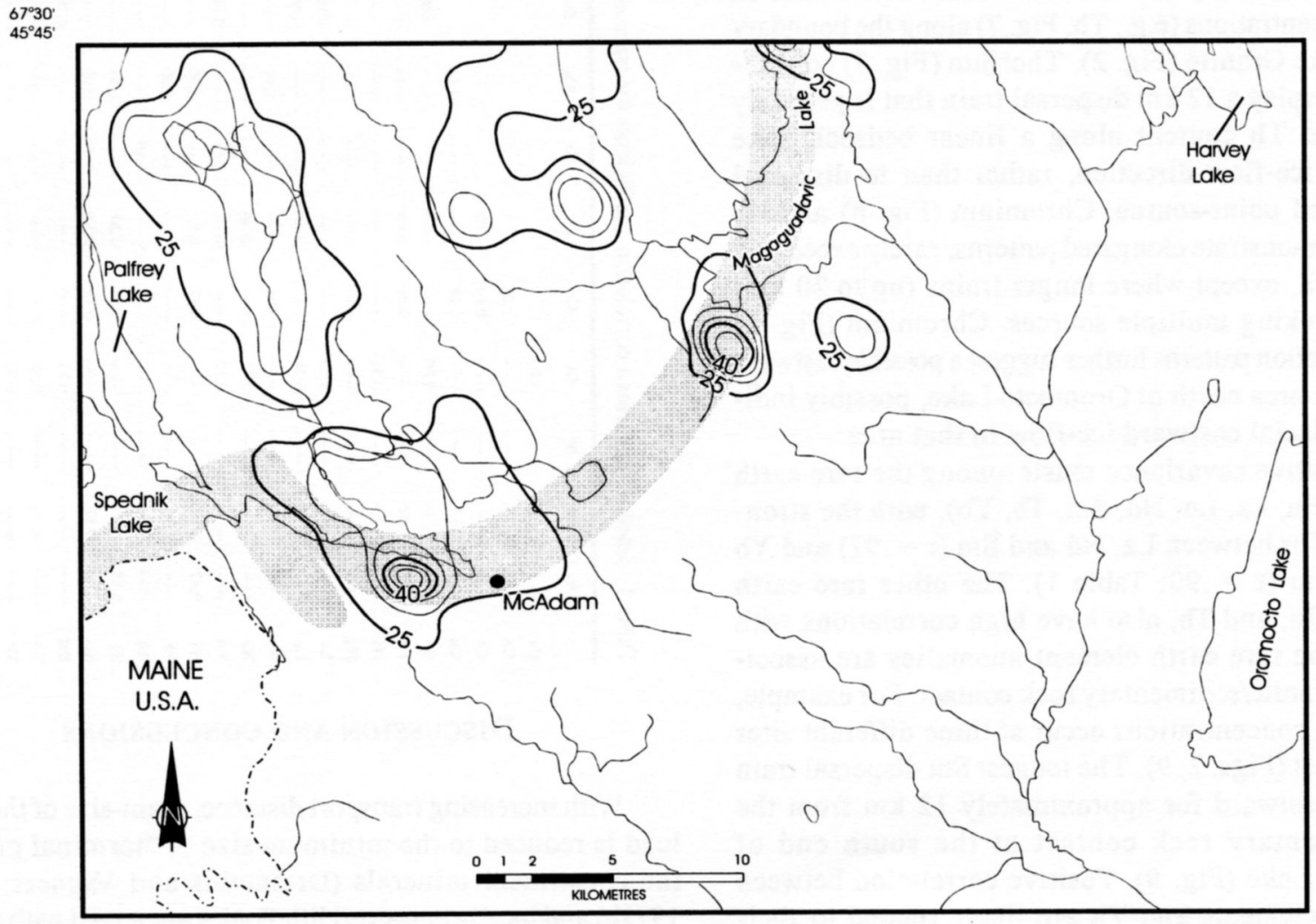

Fig. 7. Th concentration in till (contour interval $5 \mathrm{ppm}$ ). The shaded line denotes the approximate boundary between granitic rocks to the north and sedimentary rocks to the south. 


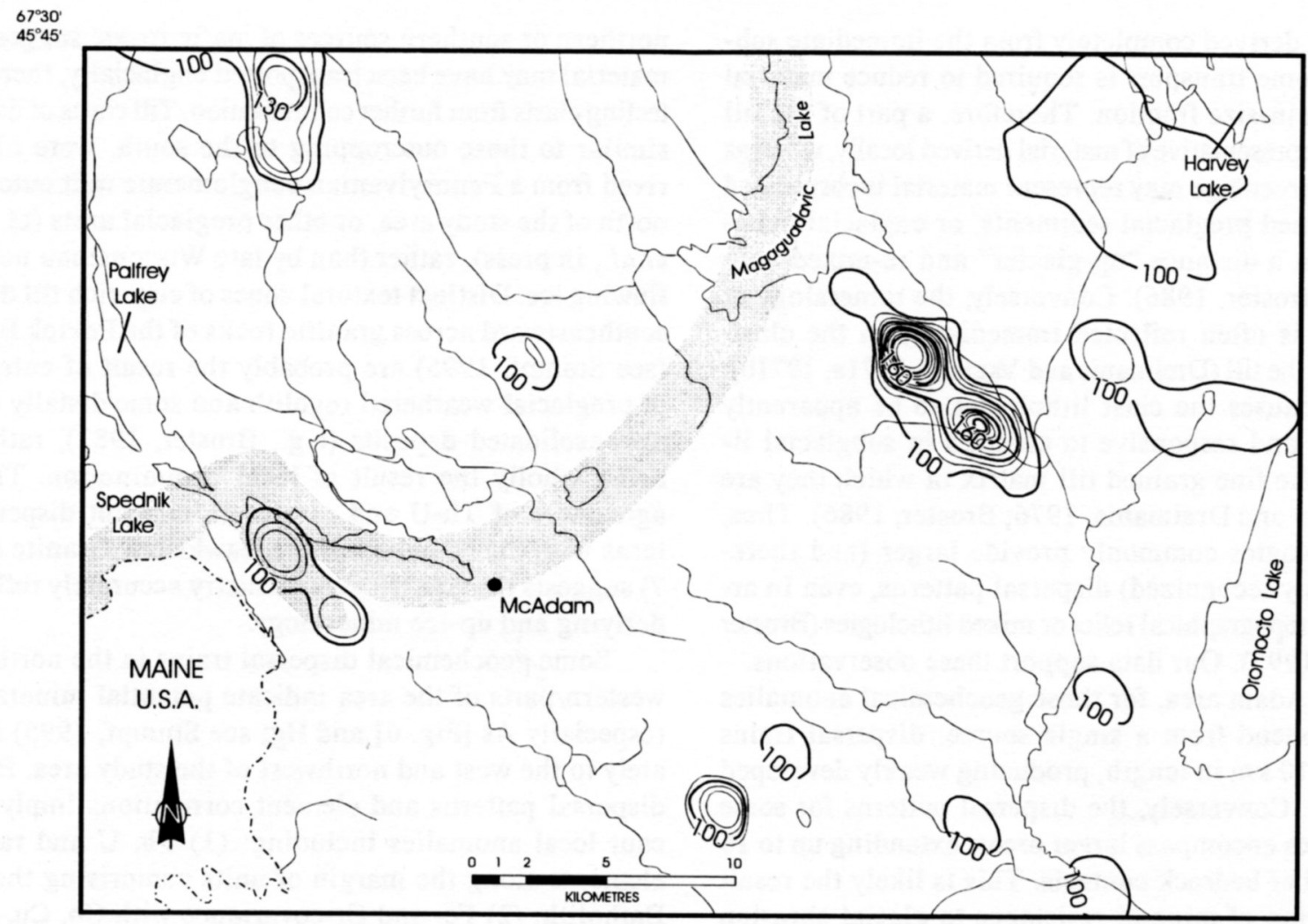

$6700^{\circ}$

Fig. 8. $\mathrm{Cr}$ concentrations in till (contour interval $10 \mathrm{ppm}$ ). The shaded line denotes the approximate boundary between granitic rocks to the north and sedimentary rocks to the south. Note the influence of eastward glacial dispersal at the eastern edge of the area.

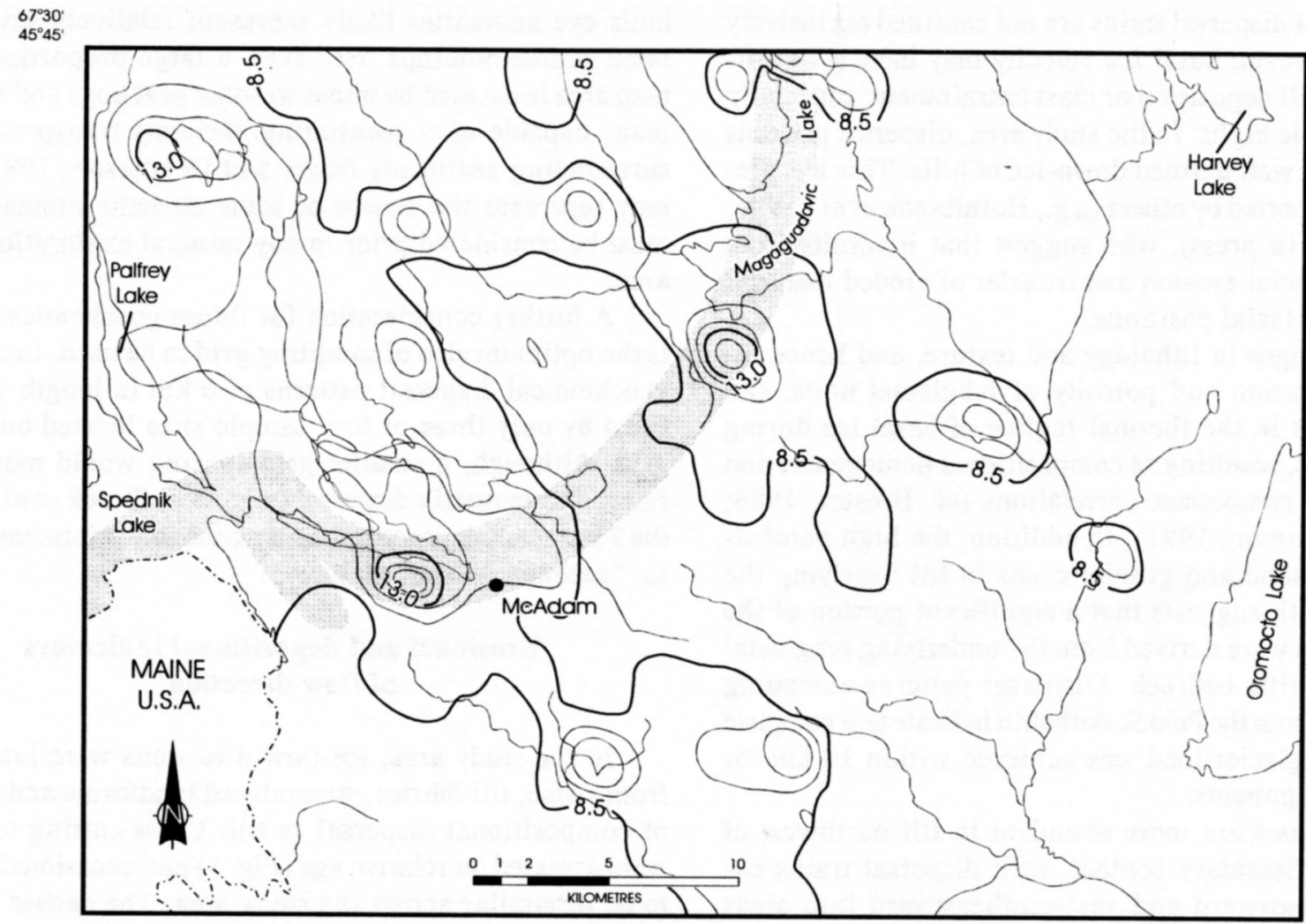

Fig. 9. Sm concentration in till (contour interval $1.5 \mathrm{ppm}$ ). The shaded area denotes the approximate location of the boundary between granitic (northward) and sedimentary (southward) rocks. 
not commonly derived completely from the immediate substrate. Also, some transport is required to reduce material to the finer grain-size fraction. Therefore, a part of the till matrix can be representative of material derived locally, whereas a significant percentage may represent material incorporated from fine grained preglacial sediments, or englacial materials derived at a distance "up-glacier" and re-mixed with local debris (Broster, 1986). Conversely, the mineralogy of local bedrock is often reflected immediately in the clastsize fraction of the till (Dreimanis and Vagners, 1971a, 1971b). This process causes the clast lithologies to be apparently more variable and responsive to changes in subglacial lithology than the fine grained till matrix in which they are deposited (May and Dreimanis, 1976; Broster, 1986). Thus, till clast lithologies commonly provide larger (and therefore more easily recognized) dispersal patterns, even in areas of complex topographical relief or mixed lithologies (Broster and Huntley, 1995). Our data support these observations.

In the McAdam area, for those geochemical anomalies that clearly extend from a single source, dispersal trains rarely exceed $10 \mathrm{~km}$ in length, producing weakly developed areal patterns. Conversely, the dispersal patterns for some clast lithologies encompass larger areas, extending up to 16 km southward of bedrock contacts. This is likely the result of a combination of mineral resistance to glacial abrasion (Broster $e t$ al., in press), the effect of topography and basal ice velocity (Clark, 1987: pp. 528-529), and the size of source outcrop. Valley topography seems to be less of a controlling factor in the central part of the study area, since granulometric and lithological dispersal trains are not confined exclusively to valleys. However, basal ice velocity may have a significant effect on till deposition or clast entrainment, especially near topographic highs. In the study area, dispersal patterns are specifically well defined down-ice of hills. This has previously been reported by others (e.g., Hornibrook et al., 1991; Broster et al., in press), who suggest that it results from preferential glacial erosion and transfer of eroded material into higher englacial positions.

Rapid changes in lithology and texture, and hence resistance to abrasion and porosity of subglacial units, can induce changes in the thermal regime of basal ice during glacial advance, resulting in compositional homogenization and obscuring component correlations (cf. Broster, 1986; Broster and Seaman, 1991). In addition, the high percentage of matrix sand and granite clasts in till overlying the Pokiok Batholith suggests that a significant portion of the local sediments were derived from the underlying preglacial weathered granitic bedrock. Dispersal patterns extending southeastward from the Pokiok Batholith indicate that complete mixing of the glacier load was achieved within $10 \mathrm{~km}$ for the matrix components.

Granite clasts are more abundant in till northwest of the granite-sedimentary contact, with dispersal trains extending southeastward and east-southeastward into areas underlain by sedimentary units (Fig. 4). In contrast, sedimentary clasts increase significantly, only eastward and southeastward of the Pokiok Batholith (Fig. 5). The occurrence of distally derived clasts, in excess of $20 \mathrm{~km}$ from possible northern or southern sources of mafic rocks, suggests some material may have been transported englacially, thereby protecting clasts from further comminution. Till clasts of lithologies similar to those outcropping to the south, were likely derived from a Pennsylvanian conglomerate unit outcropping north of the study area, or other preglacial units (cf. Broster et al., in press), rather than by late Wisconsinan northward flowing ice. Distinct textural zones of clay-rich till dispersed southeastward across granitic rocks of the Pokiok Batholith (see Stumpf, 1995) are probably the result of entrainment of preglacial weathered regolith and some distally derived, unconsolidated deposits (e.g., Broster, 1982), rather than being wholly the result of local comminution. The close agreement of Th- $U$ and rare earth element dispersal patterns with the boundary of the Hawkshaw Granite (Figs. 2, 7) suggests that the till geochemistry accurately reflects underlying and up-ice mineralogy.

Some geochemical dispersal trains in the northern and western parts of the area indicate potential mineralization (especially As [Fig. 6] and Hg; see Stumpf, 1995) immediately to the west and northwest of the study area. Bulls-eye dispersal patterns and element correlations imply significant local anomalies including: (1) Th, $U$ and rare earth elements along the margin of units comprising the Pokiok Batholith; (2) $\mathrm{Fe}$ - and $\mathrm{Cr}$-covariance with $\mathrm{Co}, \mathrm{Cu}, \mathrm{Mn}, \mathrm{Ni}$, $\mathrm{Pb}$, particularly (a) $6 \mathrm{~km}$ west of McAdam, (b) immediately southeast of Magaguadavic Lake and (c) in the northwest corner of the area; and (3) high As-Hg concentrations in the northwestern corner of the study area. Single sample, bulls eye anomalies likely represent relatively small, isolated source outcrops. However, a large proportion of the map area is covered by minerotrophic peat bogs and swamps, many capable of concentrating elements transported from surrounding sediments (Keys and Henderson, 1983). This may represent the source of some element anomalies and must be considered prior to any mineral exploration of the area.

A further consideration for future geochemical studies is the optimum size of sampling grid to be used. In the area, geochemical dispersal patterns of $6 \mathrm{~km}$ in length were defined by only three or four sample sites located on a $2-\mathrm{km}$ grid. Although, a smaller grid-spacing would more accurately define matrix dispersal (e.g., Hornibrook et al., 1991), the $2 \mathrm{~km}$ spacing appears to be a reasonable minimum spacing for "reconnaissance" studies.

\section{Erosional and depositional indicators of flow direction}

In the study area, ice-flow directions were interpreted from striae, till fabrics, streamlined landforms and patterns of compositional dispersal in till. Cross-cutting striations were assessed on relative age (Fig. 3 ) and occasionally found to be dissimilar across the study area. The earlier flow direction at one site would represent the last flow direction at another site and vise versa. At many locations, bimodal fabrics agreed with both directions and it was not possible to distinguish between parallel and transverse fabrics. 
Some difference in striae orientation can be attributed to the interactions between topography and glacier physiography. For example, Broster $(1991$, p. 18) suggests that for most glaciers, the ice at glacial margins is relatively thin and susceptible to variation in local relief. Thus, during early advance of thin ice and during late movements of ablating and thinning margins, striae directions are likely to be controlled by topographic relief; whereas in areas of thick ice, or as thicker parts of a glacier flows over an area, regional flow patterns develop that can differ with earlier and later "topographically-controlled" directions (Broster, 1991).

Dispersal patterns of till components reflect ice movements during and after entrainment. The dispersal patterns in the area indicate two main directions of flow. The major direction is southeastward (Figs. 4, 5, 7, 8), parallel to the orientation of the major streamlined bedrock features. This ice-flow direction is the dominant orientation reported previously for southwestern New Brunswick (Matthew, 1872; Chalmers, 1890, 1898; Lee, 1957, 1962; Gadd, 1973; Rampton et al., 1984; Balzer and Broster, 1994) and may be correlative to the Tay and Caledonia flow patterns of Rampton $e t$ al. (1984). The second direction of flow is east-southeastward (clasts; Figs. 4, 5; Cr; Fig. 8). However, these secondary directions are prevalent only in parts of the area and may represent local influences (topographic or substrate) or interaction with other ice masses (Seaman, 1991).

In the McAdam area, ice-flow directions as indicated by dispersal patterns are much less complex than those recorded by striae. Consequently, for drift exploration, source units are best defined by examination of dispersal patterns for clasts or matrix components (e.g., Hicock, 1986; Hornibrook et al., 1991, 1993; Seaman, 1991; Broster and Huntley, 1995), rather than by striae or other small erosion features.

\section{Acknowledgements}

Funding was provided by the Geological Surveys Branch of the New Brunswick Department of Natural Resources and Energy (NBDNRE). Sample collection and geochemical analyses were funded by NBDNRE operating budgets to Seaman and NBDNRE Research Contracts to Broster. Additional support was received from an NSERC operating grant to Broster. Some of the data presented here represents part of a UNB graduate project by Stumpf. The authors are grateful to Les Fyffe for assisting in clast lithology identifications, Rex Boldon for sample preparation, and to Angel Gomez for improvements to figures. We also thank Ron DiLabio and Mike Parkhill for review of an earlier manuscript.

BALzer, S.A. 1992. Quaternary geology and dispersal patterns of the Canterbury area, New Brunswick. New Brunswick Department of Natural Resources and Energy, Mineral Resources, Open File Report 92-5, 192 p.

Balzer, S.A. and Broster, B.E. 1994. Comparison of clast and matrix dispersal in till: Canterbury area, New Brunswick. Atlantic Geology, 30, pp. 9-17.

Bostock, H.S. 1970. Physiographic subdivisions of Canada. In Geology and Economic Minerals of Canada. Edited by R.J.W.
Douglas. Geological Survey of Canada, Economic Geology Report 1, pp. 10-30.

Bouyoucos, G.J. 1962. Hydrometer method improved for making particle size analyses of soils. Agronomy Journal, 54(5), pp. $464-465$.

Broster, B.E. 1982. Compositional variations in the St. Joseph till units of the Goderich area, Ontario. Ph.D thesis, the University of Western Ontario, London, Ontario, 103 p.

-..-- 1986. Till variability and compositional stratification: examples from Port Huron lobe. Canadian Journal of Earth Sciences, 23, pp. 1823-1841.

-.--- 1991. Glaciotectonic deformation in sediment and bedrock, Hat Creek, British Columbia. Géographie physique et Quaternaire, 45, pp. 5-20.

Broster, B.E. and Dreimanis, A. 1981. Deposition of multiple lodgement tills by competing glacial flows in a common ice sheet: Cranbrook, British Columbia. Arctic and Alpine Research, 13, pp. 197-204.

Broster, B.E. and Huntley, D.H. 1995. Effective low-cost reconnaissance drift prospecting in areas of variable terrain: an example from the south-east Taseko Lakes area, central British Columbia. In Drift Exploration in the Canadian Cordillera. Edited by P.T. Bobrowsky, S.J. Sibbick, J.H. Newell, and P.F. Matysek. British Columbia Ministry of Energy, Mines and Petroleum Resources, Paper 1995-2, pp. 121-126.

Broster, B.E. and SEAMAN, A.A. 1991. Glacigenic rafting of weathered granite: Charlie Lake, New Brunswick. Canadian Journal of Earth Sciences, 28, pp. 649-654.

Broster, B.E., MunN, M.D., and Pronk, A.G. (In press). Inferences on glacial dynamics from till clast dispersal: Waterford area, New Brunswick. Géographie physique et Quaternaire.

CARon, A. 1996. Geology of the Pokiok Batholith aureole, with emphasis on the Lake George Mine, York County, New Brunswick. New Brunswick Department of Natural Resources and Energy, Minerals and Energy Division, Geoscience Report 942, $91 \mathrm{p}$.

Chalmers, R. 1890. Surface geology of southern New Brunswick. Geological Survey of Canada, Annual Report, 1888-1890, v. 4, Part N.

---- 1898. Report on the surface geology and auriferous deposits of south-eastern Quebec. Geological Survey of Canada, Annual report, X (1897), Part J, 160 p.

-.-- 1902. Report on the surface geology shown on the Fredericton and Andover quarter-sheet maps, New Brunswick. Geological Survey of Canada, Annual Report, v. XII (1899), Part M, 41 p.

Clark, P.U. 1987. Subglacial sediment dispersal and till composition. Journal of Geology, 95, pp. 527-541.

Clark, R.K. 1961 a. Geology, McAdam (east half), York, and Charlotte counties, New Brunswick. New Brunswick Department of Natural Resources, Mines Branch, Plate 59-4.

-.-.- 1961b. Geology, McAdam (west half), York, and Charlotte counties, New Brunswick. New Brunswick Department of Natural Resources, Mines Branch, Plate 59-4a.

Dilabio, R.N.W. 1990. Chapter 7: Glacial dispersal trains. In Glacial Indicator Tracing. Edited by R. Kujansuu and $M$. Saarnisto. A.A. Balkema, Rotterdam, pp. 109-122.

Dreimanis, A. 1958. Tracing ore boulders as a prospecting method in Canada. Canadian Mining and Metallurgical Transactions, 61, pp. $49-56$

Dreimanis, A. and Vagners, U.J. 1971a. Bimodal distribution of rock and mineral fragments in basal tills. In Till: a Symposium. Edited by R.P. Goldthwait. Ohio State University Press, pp. 237-250. 
-.-- 19971b. The effect of lithology upon texture of till. In Research Methods in Pleistocene Geomorphology. Edited by E. Yatsu and A. Falconer. 2nd Guelph Geomorphology Symposium, Guelph, Ontario, pp. 66-82.

FyFfE, L.R. 1989. Lithogeochemistry (Co, Ni, Cu, $\mathrm{Zn}, \mathrm{Pb}, \mathrm{As}$, $\mathrm{Mo}, \mathrm{Ag}, \mathrm{Sb}, \mathrm{W}, \mathrm{Au}, \mathrm{Pt}, \mathrm{Pd}$ ) of the McAdam - St. Croix area, New Brunswick (NTS $21 \mathrm{G} / 11 \mathrm{c}$, d, and $21 \mathrm{G} / 6 \mathrm{e}$ ). New Brunswick Department of Natural Resources and Energy, Mineral and Energy Division, Geological Notes Series PM 89-70, 8 p.

FYFFE, L.R. and FRICKER, A. 1987. Tectonostratigraphic terrane analysis of New Brunswick. Maritime Sediments and Atlantic Geology, 23, pp. 113-122.

GADD, N.R. 1973. Quaternary geology of southwest New Brunswick with particular reference to Fredericton area. Geological Survey of Canada, Paper 71-34, 31 p. and Map 12-1971, scale 1:250,000.

Hawkes, H.E. and WebB, J.S. 1962. Geochemistry in Mineral Exploration. Harper and Row Publishers, Incorporated, New York.

Hicock, S.R. 1986. Pleistocene glacial dispersal and history in Buttle valley, Vancouver Island, British Columbia: a feasibility study for alpine drift prospecting. Canadian Journal of Earth Sciences, 23, pp. 1867-1879.

Hornibrook, E.R.C., Broster, B.E., Gardiner, W.W., and Pronk, A.G. 1991. Glacial dispersal of heavy minerals in late Wisconsinan till, central New Brunswick. Atlantic Geology, 27, pp. 199208.

---- 1993. Glacial dispersion of garnets and other heavy minerals in till: Miramichi area, New Brunswick. Exploration and Mining Geology, 2, pp. 345-353.

Keys, D. and Henderson, R.E. 1983. An investigation of the peat resources of New Brunswick. New Brunswick Department of Natural Resources and Energy, Minerals and Energy Division, Open File Report 83-10, Plates 83-10 (A-F), and Map 18.

LEE, H.A. 1957. Surficial geology of Fredericton, York and Sunbury counties, New Brunswick. Geological Survey of Canada, Map 24-1959.

-..- 1962. Surficial geology of Canterbury, Woodstock, Florenceville, and Andover map-areas; York, Carelton, and Victoria counties, New Brunswick (Parts of $21 \mathrm{G} / 14,21 \mathrm{~J} / 4,21 \mathrm{~J} / 5$, and $21 \mathrm{~J} / 12$ ). Geological Survey of Canada, Topical Report, 33, $16 \mathrm{p}$.

Lutes, G.G. 1987. Geology and geochemistry of the Pokiok Batholith, New Brunswick. New Brunswick Department of Natural Resources and Energy Division, Report of Investigation 22, $55 \mathrm{p}$.

Matthew, G.F. 1872. On the surface geology of New Brunswick. Canadian Naturalist, 6, pp. 326-328; 7, pp. 433-454, 1875.

May, R.W. and Dreimanis, A. 1976. Compositional variability in tills. In Glacial Till. Edited by R.F. Legget. Royal Society of Canada, Special Publication 12, pp. 99-119.

McLeod, M.J, Johnson, S.C., and Ruitenberg, A.A. 1994. Geological map of southwestern New Brunswick. New Brunswick Department of Natural Resources and Energy, Mineral Resources, Map NR-5.

Munn, M.D., Broster, B.E., and Pronk, A.G. 1996. Geochemical dispersal in till: Waterford area, New Brunswick. Atlantic Geology, 32, pp. 269-279.
Newell, J.M. and Bruce, G.S.W. 1956. Report - NB Uranium Metals and Mining Limited. Property Harvey District, York County, New Brunswick, 7 p.

Pronk, A.G., Bobrowsky, P.T., and Parkhill, M.A. 1989. An interpretation of the late Quaternary glacial flow indicators in the Baie de Chaleurs region, northern New Brunswick. Géographie physique et Quaternaire, 43, pp. 179-190.

Rampton, V.N., Gauthier, R.C., Thibault, J., and Seaman, A.A. 1984. Quaternary geology of New Brunswick. Geological Survey of Canada, Memoir 416, 77 p. + Map 1594A, scale $1: 500,000$.

Ruitengerg, A.A., Fyffe, L.R., McCutcheon, S.R., St. Peter, C.J., IRRINKI, R.R., and Venugopal, D.V. 1977. Evolution of preCarboniferous tectonostratigraphic zones in the New Brunswick Appalachians. Geoscience Canada, 4, pp. 171- 181.

SeAman, A.A. 1982. Granular aggregate resources, McAdam (NTS $21 \mathrm{G} / 11$ ) and Forest City (NTS 21 G/12). New Brunswick Department of Natural Resources, Mineral Resources Division, Open File Report 82-14, 101 p.

...- 1989. Glacial striae trends in New Brunswick: a compilation. New Brunswick Department of Natural Resources and Energy, Minerals and Energy Division, Open File Report 89-34.

-..-- 1991. Complex glacial ice-flow events in New Brunswick with particular reference to the Oromocto Lake area, and implications for drift prospecting. New Brunswick Department of Natural Resources and Energy, Mineral Resources, Geoscience Report 89-2, 48 p.

.... 1993. Preliminary report - Au, Ag, As, Hg, Sb and base metal values for till samples from the Fosterville (NTS $21 \mathrm{G} /$ 13) map area, York and Carleton counties, New Brunswick. New Brunswick Department of Natural Resources and Energy, Mineral Resources, Open File Report 93-7, 28 p.

-..- 1995. Till pebble dispersal patterns in the Forest City (NTS $21 \mathrm{G} / 12$ ) and Fosterville (NTS $21 \mathrm{G} / 13$ ) map areas, York and Carleton counties, New Brunswick. New Brunswick Department of Natural Resources and Energy, Minerals and Energy Division, Miscellaneous Report 18, pp. 213-223.

Seaman, A.A., Broster, B.E., Cwynar, L.C., Lamothe, M., Miller, R.F., and Thibault, J.J. 1993. Field guide to the Quaternary geology of southwestern New Brunswick. New Brunswick Department of Natural Resources and Energy, Mineral Resources, Open File Report 93-1, 102 p.

Shilts, W.W. 1976. Glacial till and mineral exploration. In Glacial Till: an Interdisciplinary Study. Edited by R.F. Legget. Royal Society of Canada, Special Publication No. 12, pp. 205-224.

-.-- 1984. Till geochemistry in Finland and Canada. Journal of Geochemical Exploration, 21, pp. 95-117.

STUMPF, A.J. 1995. Quaternary geology and dispersal patterns of the McAdam (NTS $21 \mathrm{G} / 11$ ) map area, York County, New Brunswick. New Brunswick Department of Natural Resources and Energy, Minerals and Energy Division, Open File Report 95-5, $218 \mathrm{p}$.

Stumpf, A.J., Seaman, A.A., and Broster, B.E. 1996. Surficial geology of the McAdam (NTS 21 G/11) map area, New Brunswick. New Brunswick Department of Natural Resources and Energy, Minerals and Energy Division, map scale 1:50,000. 